\title{
DETERMINATION OF ZINC AND CADMIUM IN ANTI- DANDRUFF SHAMPOOS AVAILABLE AT THE LIBYAN MARKET BY ATOMIC ABSORPTION
}

\author{
Fouziya mabrouk Samhoud ${ }^{1}$, Entesar Emhamed Abouglaida ${ }^{2}$, Munsif \\ Abubakr Ahmed ${ }^{3}$ \\ ${ }^{1}$ Department of Petro-chemistry, Higher Institute of water Affairs- Agielat- Libya \\ ${ }^{2,3}$ Department of Environmental Sciences and Pollution, Higher Institute of water Affairs- \\ Agielat- Libya \\ som73a8.7@gmail.com
}

\begin{abstract}
The present study is carried out to measure zinc and cadmium in twenty samples of anti-dandruff shampoo products commercially available in the local cosmetic markets in Libya. Detection of zinc and cadmium were done by Flame Atomic Absorption Spectrophotometry (FAAS) method. The results showed that cadmium concentration ranged between 0.017 and 9.37 mg. $\mathrm{kg}^{-1}$ while zinc concentration ranged between $25.9 \mathrm{mg} \mathrm{kg}^{-1}$ and $8300 \mathrm{mg} \cdot \mathrm{kg}^{-1}$. These measurements indicated that cadmium and zinc contents in the investigated samples were higher than WHO limits; suggesting that chronological use of these shampoo products would impose serious health risks to human users. Therefore, quality control and concentration optimism should be implemented to assure the safety of cosmetic products. This also can be achieved by improving the processing and manufacturing practices in the industry.
\end{abstract}

Keywords: zinc, cadmium, spectrometry, cosmetic shampoos, anti-dandruff

\section{Introduction}

Dandruff is a condition in which white scales of dead skin are shed by the scalp. It develops as a natural process of renewing epidermal cells in the skin of the scalp. Dandruff is the remains of dead skin cells that can be replaced by new cells (Amartey et al., 2011). The development of dandruff is usually associated with itching and redness to human skin. To overcome this health problem, human use cosmetic and body care products. However, in the last few decades, cosmetic industry has grown rapidly over the world and produced wide range varieties of cosmetics for the care and beautification of the skin, hair, nails, teeth and body. These products can also be found in different forms to meet the customer requirements, such as screams, soaps, powders, lotions, oils, dyes, perfumes and lipsticks (Amartey et al.,2011; Iwegbue et al., 2015). However, scientific research has shown that these products might have adverse effects on human health. This includes reproduction, neurological and 
dermal ailments (Umar \& Caleb, 2013: Iwegbuea et al., 2016b). Heavy metal contaminants are responsible for these problems. Heavy metals such as lead, zinc and cadmium are common contaminants in different types of cosmetic products (Nnoromet et al., 2005: Chauhan et al., 2010). For instance, cadmium is a highly persistent pollutant and categorized by the Agency for Toxic Substances and Disease Registry (2012) as one of the top-ten hazardous chemicals. Metallic compounds in hygienic products, such as shampoos are known for their antidandruff effect. Similarly, zinc pyrithione and selenium sulfides have fungi static and fungicidal action against Pityrosporum, and they play a pathogenic role in seborrhea dermatitis and dandruff. Selenium and cadmium formulations are useful adjuncts in the treatment of tinea capitis, a common cause of dandruff. Increased concentrations of zinc pyrithione or and selenium sulfide are restricted to pharmaceutical end points due to their allergic effects on skin (Nnorom et al., 2005). For cadmium sulfide, it is toxic and not widely used in cosmetic formulations (Salvador et al., 2000). Therefore, the establishment of content of these metals in cosmetic products is imperative in order to protect human health and to improve the quality of the products. According to the directions set by the European Community Directives (ECD), cosmetic formulations containing more than $1 \%$ of selenium sulfide, $0.5 \%$ of zinc pyrithioneup, and $1 \%$ of other zinc salts are prohibited in the cosmetic industry (Esemedafe \& Ogagaoghene 2016; Karimi \& Ziarati, 2015). The maximum allowable limit for $\mathrm{Cd}$, as an impurity in cosmetic products is set at $3.0 \mu \mathrm{g} / \mathrm{g}$ in Canada (Health Canada, 2012; Iwegbuea et al., 2017: Dghaimet al., 2015), and 5.0 $\mu \mathrm{g} / \mathrm{g}$ in Germany; compared to WHO limit of $0.3 \mu \mathrm{g} / \mathrm{g}$ (Iwegbue et al., 2015; Iwegbuea et al., 2017; Faruruwa \& Bartholomew 2014). For zinc, WHO recommends the concentrations of $100 \mu \mathrm{g} / \mathrm{g}$ and $200 \mu \mathrm{g} / \mathrm{g}$ to be used as minimum and maximum allowable limits (BfR, 2006; Iwegbue et al., 2016a)

\section{Experimental Work}

\section{Method and Materials}

The chemical analysis method used in this study was the flame atomic absorption spectrometry (FAAS). A Varian AA-10 FAAS instrument was used to measure Zn and $\mathrm{Cd}$ contents. This spectrometer is widely used in testing antidandruff shampoos as prescribed by previous workers (Iwegbuea et al., 2016c; Faruruwa \& Bartholomew, 2014). Other laboratory materials used for the analysis included concentrated nitric acid $\mathrm{HNO}_{3} \% 65$, concentrated sulfuric acid $\mathrm{H}_{2} \mathrm{SO}_{4} \% 98$ and sodium chloride $\mathrm{NaCl}$. All of the materials were of analytical grade quality. The concentration of elements was calculated in $\mathrm{mg} / \mathrm{kg}$ units using the following equation (Zainy, 2015):

Concentration $\mathrm{mg} / \mathrm{kg}=($ Concentration $\mathrm{mg} / \mathrm{l} \times$ volume $\mathrm{l} \div$ weight $\mathrm{kg}) \ldots \ldots \ldots . .($ Eq. 1$)$

\section{Sample preparation}


Twenty-two antidandruff shampoos of different origin were collected from local markets in Libya. In these samples, zinc content was present in the pyritionateor sulfate form, whereas cadmium content was in the sulfide form. Other components found in the formulations of the samples included ten bioactive, diverse organic polymers, fragrance agents, softening creams, aluminum-magnesium silicate (only in cadmium samples)and water.

The sample preparation done in the lab was in accordance with the procedure undertaken by Bocca et al.(2014). A sample fraction of $0.1 \mathrm{~g}$, weighed by an electronic balance, was added to $2 \mathrm{ml}$ digestion solution $(70 \%$ nitric acid, $30 \%$ sulphuric acid). The mixture was capped tightly and placed in an oven at $60^{\circ} \mathrm{C}$ for 12 hours. The mixture then was cooled before a volume of $6 \mathrm{~mL}$ distillated water was added to. Finally, $2 \mathrm{~mL} \mathrm{NaCl}$ solution was added to the mixture.

\section{Results and Discussion}

Table 1:Concentrations of heavy metals in some antidandruff shampoos obtainedin the Libyan markets.

\begin{tabular}{|c|c|c|c|}
\hline Sample NO & Country of made & $\mathrm{Zn}(\mathrm{mg} / \mathrm{kg})$ & $\mathrm{Cd}(\mathrm{mg} / \mathrm{kg})$ \\
\hline 1 & Algiers & 1940 & 4.5 \\
\hline 2 & USA & 37 & 3.3 \\
\hline 3 & India & 39 & 2.9 \\
\hline 4 & Saudi Arabia & 8300 & 3 \\
\hline 5 & Tunisia & 1560 & 3.3 \\
\hline 6 & Turkey & 71.1 & 3.1 \\
\hline 7 & Malaysia & 1436 & 4.1 \\
\hline 8 & Tunisia & 27 & 3.5 \\
\hline 9 & P.R.C & 46.4 & 3.1 \\
\hline 10 & Libya & 34.1 & 3.7 \\
\hline 11 & Saudi Arabia & 31.3 & 3.9 \\
\hline 12 & Turkey & 38.5 & 3.7 \\
\hline 13 & Germany & 32.5 & 3.5 \\
\hline 14 & Turkey & 26.5 & 2.9 \\
\hline 15 & Tunisia & 142.2 & 3.5 \\
\hline 16 & Turkey & 1332.87 & 0.017 \\
\hline 17 & Spain & 36.2 & 4.4 \\
\hline 18 & Italy & 25.9 & 3.5 \\
\hline 19 & Bahrain & 28.9 & 3.9 \\
\hline 20 & $\mathrm{EU}$ & 42.0 & 3.6 \\
\hline 21 & Libya & 106.68 & 0.058 \\
\hline 22 & U.A & 40.1 & 9.37 \\
\hline
\end{tabular}

Table 1 shows the results of the collected samples. The results showed that the sample concentration levels vary between 0.017 to $9.37 \mathrm{mg} / \mathrm{kg}$ for $\mathrm{Cd}$ and 25.9 to 
$8300 \mathrm{mg} / \mathrm{kg}$ for $\mathrm{Zn}$, respectively. For cadmium concentration, the majority of the samples had higher values than the WHO permissible limit $(0.3 \mu \mathrm{g} / \mathrm{g})$, with the highest in sample number 22 and the lowest in sample number16 (Figure 1). For Zn concentration, all of the sample values $(25.9-8300 \mathrm{mg} / \mathrm{kg})$ exceeded the WHO permissible limit $(100 \mu \mathrm{g} / \mathrm{g})$, with the highest in sample number 4 and the lowest in sample number 18. (Figure 2).

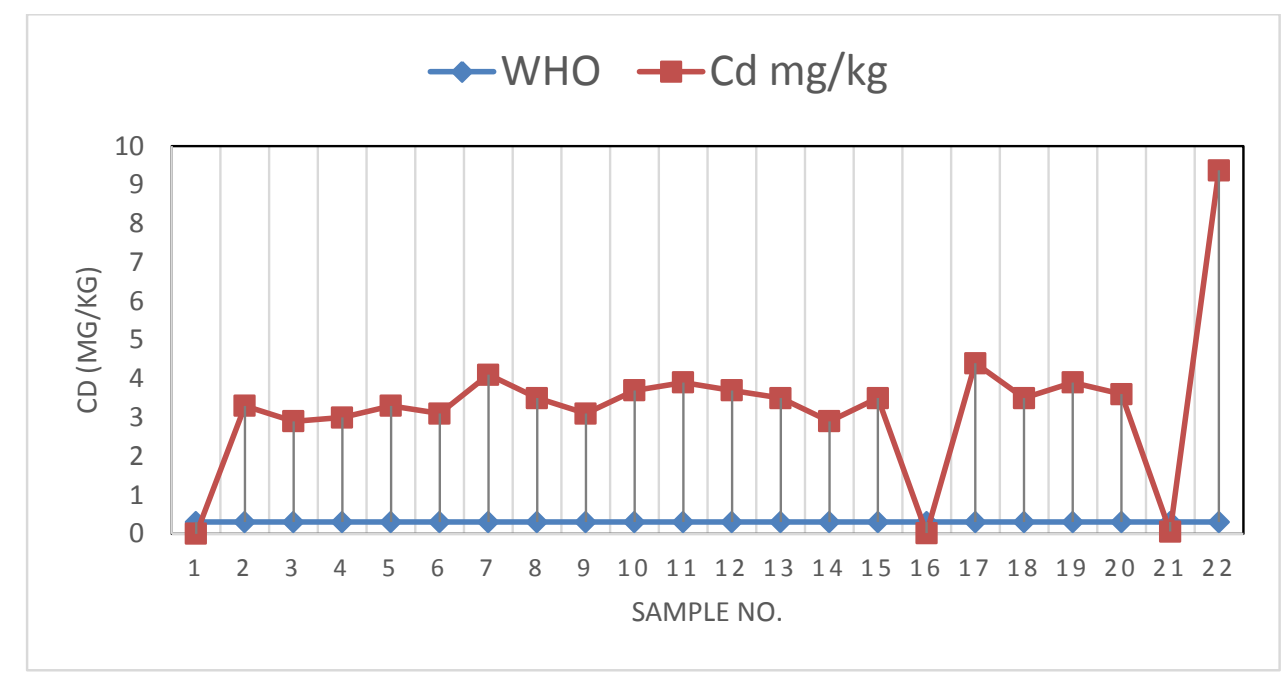

Figure 1: Cadmium concentration in sample antidandruff shampoos compared with WHO limit

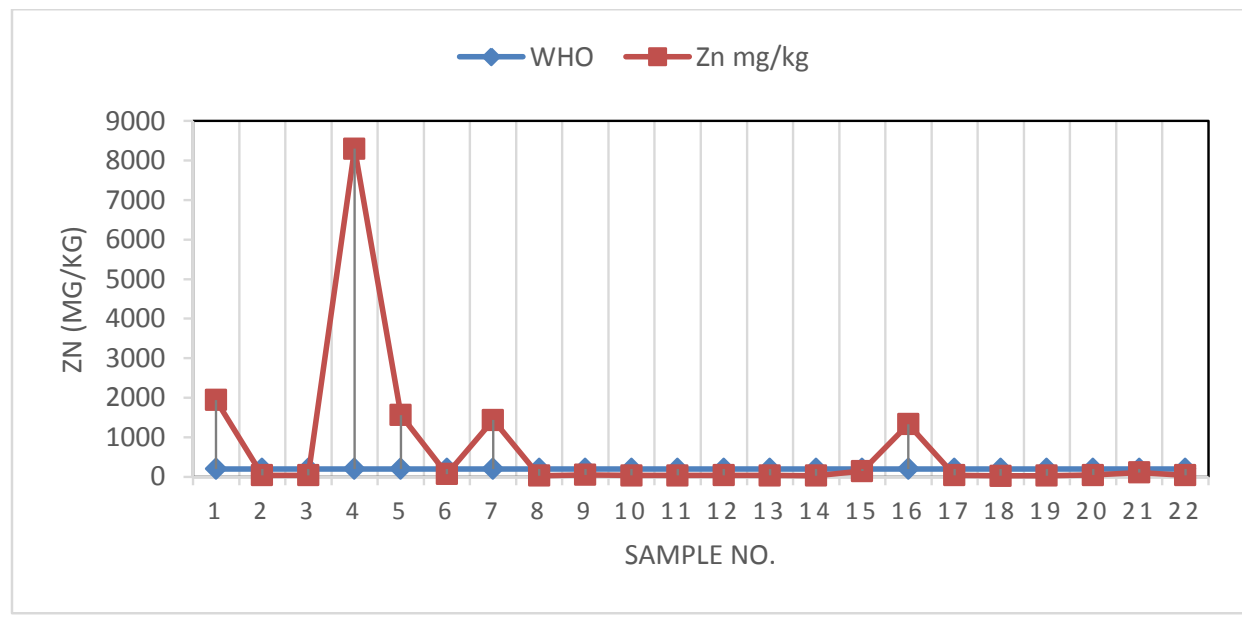

Figure 2: Zinc concentration in sample antidandruff shampoos compared with WHO limit

The results indicated that the obtained Cd concentration was generally higher than the levels found in shampoo products widely marketed in Middle East and Asia 
regions (see Table 2). Ullah et al. (2013) conducted a FAAS analysis for 15 cosmetic products from imported sources as well as locally manufactured items in Pakistan. The investigated products included three ordinary shampoos, three talc powders, three lipsticks, three kohl samples, and three cream samples. Chauhan et al . (2010) investigated shampoo samples by FAAS, and the values ranged between 0.9 and $1500 \mu \mathrm{g} / \mathrm{g}$ for $\mathrm{Zn}$, and 0.33 and $0.042 \mu \mathrm{g} / \mathrm{g}$ for $\mathrm{Cd}$. Although the cadmium in some of the samples was in trace amount, the chronic exposure to more than $0.005 \mathrm{ppm}$ of Cd might potentially impose risk to human health (Iwegbuea et al., 2016b). However, the severity of Cd hazard exposure depends on multiple factors, such as rate of product use, age, body sensitivity, and others (Ullah et al., 2013; Al-Qutob et al., 2013).

Table 2: Comparison of the results of the present study with previous studies in the world

\begin{tabular}{|c|c|c|c|}
\hline $\begin{array}{l}\text { Heavy } \\
\text { metal }\end{array}$ & Concentration range $(\mu \mathrm{g} / \mathrm{g})$ & Product name & References \\
\hline $\mathrm{Zn}, \mathrm{Cd}$ & $\begin{array}{l}25.9 \text { to } 83000.017(\mathrm{Zn}) \\
0.017 \text { to } 9.37(\mathrm{Cd})\end{array}$ & Antidandruff shampoos & This work \\
\hline $\mathrm{Cd}$ & 0.09 to 5.2 & Skin whitening creams & $\begin{array}{l}\text { ALqadamiet et al. } \\
\text { (2013) }\end{array}$ \\
\hline $\mathrm{Cd}$ & 0.625 to 1.875 & Oily preparations & $\begin{array}{l}\text { Sukender } \text { et al. } \\
\text { (2012) }\end{array}$ \\
\hline $\mathrm{Zn}, \mathrm{Cd}$ & $\begin{array}{l}0.496 \text { to } 1500(\mathrm{Zn}) \\
0.058 \text { to }-0.203(\mathrm{Cd})\end{array}$ & Shampoo & Ullah et al. (2013) \\
\hline $\mathrm{Zn}, \mathrm{Cd}$ & $\begin{array}{l}1.600 \text { to } 89.500(\mathrm{Zn}) \\
4.200 \text { to } 6.800(\mathrm{Cd})\end{array}$ & Hair pomade & $\begin{array}{l}\text { Amartey et al. } \\
\text { (2011) }\end{array}$ \\
\hline $\mathrm{Cd}$ & Less than 10 to more than 50 & Eye shadow & $\begin{array}{l}\text { Nourmoradi et al. } \\
\text { (2013) }\end{array}$ \\
\hline $\mathrm{Cd}$ & 0.08 to 8.14 & Eye shadow & $\begin{array}{l}\text { Alsaffar et al. } \\
(2014)\end{array}$ \\
\hline $\mathrm{Cd}$ & 0.033 to 0.042 & Shampoo & $\begin{array}{l}\text { Chauhan et al. } \\
\text { (2010) }\end{array}$ \\
\hline $\mathrm{Cd}$ & Less than 0.002 to 3.48 & Lip products & Liu et al. (2013) \\
\hline $\mathrm{Zn}, \mathrm{Cd}$ & $\begin{array}{l}18 \text { to } 320(\mathrm{Zn}) \\
3.1 \text { to } 8.4(\mathrm{Cd})\end{array}$ & Face Powder & Liu et al. (2013) \\
\hline $\mathrm{Zn}, \mathrm{Cd}$ & $\begin{array}{l}0.7 \text { to } 185.0(\mathrm{Zn}) \\
0.8 \text { to } 18.6(\mathrm{Cd})\end{array}$ & Henna & $\begin{array}{l}\text { Nouioui et al. } \\
\text { (2016) }\end{array}$ \\
\hline $\mathrm{Cd}$ & 0.01 to 0.2 & Soap & $\begin{array}{l}\text { Orisakwe \& } \\
\text { Otaraku (2013) }\end{array}$ \\
\hline $\mathrm{Cd}$ & 0.0472 to 0.7321 & Personal care products & $\begin{array}{l}\text { Karimi \& Ziarati } \\
\text { (2015) }\end{array}$ \\
\hline $\mathrm{Zn}, \mathrm{Cd}$ & $\begin{array}{l}28.33 \text { to } 342.22(\mathrm{Zn}) \\
1.67 \text { to } 8.89(\mathrm{Cd})\end{array}$ & Personal care products & $\begin{array}{l}\text { Faruruwa et al. } \\
\text { (2014) }\end{array}$ \\
\hline $\mathrm{Zn}, \mathrm{Cd}$ & 3.2 to56.57 $(\mathrm{Zn})$ & Personal care products & Ibrahim et al. \\
\hline
\end{tabular}




\begin{tabular}{|l|l|l|l|}
\hline Zn, $\mathrm{Cd}$ & $\begin{array}{l}0.07 \text { to } 3.5(\mathrm{Cd}) \\
1.676 \text { to } 996.3(\mathrm{Zn}) \\
0.08 \text { to } 0.96(\mathrm{Cd})\end{array}$ & Personal care products & $\begin{array}{l}\text { Al-Qutobet } \text { et al. } \\
(2013)\end{array}$ \\
\hline $\mathrm{Zn}, \mathrm{Cd}$ & $\begin{array}{l}17.3 \text { to } 372.0(\mathrm{Zn}) \\
0.25 \text { to } 6.3(\mathrm{Cd})\end{array}$ & Skin moisturizing creams & $\begin{array}{l}\text { Iwegbue } \text { et al. } \\
(2015)\end{array}$ \\
\hline $\mathrm{Zn}, \mathrm{Cd}$ & $\begin{array}{l}0.7 \text { to } 2.7 \%(\mathrm{Zn}) \\
0.75 \text { to } 8.6 \%(\mathrm{Cd})\end{array}$ & Antidandruff shampoos & $\begin{array}{l}\text { Salvador } \text { et al. } \\
(2000)\end{array}$ \\
\hline $\mathrm{Zn}, \mathrm{Cd}$ & $\begin{array}{l}25.5 \text { to } 1000(\mathrm{Zn}) \\
\text { Less than } 0.06 \text { to } 3.4(\mathrm{Cd})\end{array}$ & $\begin{array}{l}\text { Bathing soaps and shower } \\
\text { gels }\end{array}$ & $\begin{array}{l}\text { Iwegbuea } \text { et al. } \\
(2017)\end{array}$ \\
\hline $\mathrm{Zn}, \mathrm{Cd}$ & $\begin{array}{l}30.0 \text { to } 1080(\mathrm{Zn}) \\
0.6 \text { to } 2.7(\mathrm{Cd})\end{array}$ & Antidandruff shampoo & $\begin{array}{l}\text { Iwegbuea } \text { et al. } \\
(2016 \mathrm{~b})\end{array}$ \\
\hline $\mathrm{Cd}$ & $\begin{array}{l}2.58 \text { to } 6.95 \\
\text { Hair care products }\end{array}$ & $\begin{array}{l}\text { Umar \& Caleb } \\
(2013)\end{array}$ \\
\hline
\end{tabular}

A wide concentration range of $\mathrm{Zn}$ has been reported for cosmetic products in the literature (Iwegbue et al., 2015). For instance, Iwegbuea et al. (2016b) reported $\mathrm{Zn}$ concentrations of $17.3-372 \mu \mathrm{g} / \mathrm{g}$ were detected in skin moisturizing and whitening creams in Nigeria, and30.0 - $1080 \mu \mathrm{g} / \mathrm{g}$ in antidandruff shampoos. The high levels were attributed to the zinc enrichment in the antidandruff formulation agent, which may pose health hazards, e.g., allergy, neurological, gastric ailment (Iwegbuea et al., 2016b; Iwegbuea et al., 2016c). Compared with our study, Zn concentration was comparable with those reported in shampoos tested in Pakistan (Ullah et al., 2013) and hair pomades in Ghana (Amartey et al., 2011).

\section{Conclusion}

The work in this study indicated that the tested antidandruff products available in the Libyan market have $\mathrm{Zn}$ and $\mathrm{Cd}$ contents higher than WHO limits. When used over long time, these shampoos may impose serious risk on human health. The findings of this study were generally similar to those established in previous works done in different countries. Therefore, there is a need for the establishment of regulations for heavy metals in personal care products, as well as imply some modifications in industry qualities to avoid human users any adverse effects imposed by these products.

\section{Recommendations}

The authors of this paper recommend interested parties to investigate other types of cosmetic products in Libya for further analysis and conformability with WHO standards. Cosmetic manufacturers are strongly advised to test their products on regular basis, even before marketing them, by certified laboratories. They are also required to publish their information about the chemical components of their products for public awareness and evaluation. 


\section{References}

- ALqadamiA.A., Abdalla Mohammad A, ALOthman Zeid A, and Omer Kamal, (2013) Applicationof Solid Phase Extraction on Multi walled Carbon Nanotubes of Some Heavy Metal Ions to Analysis of Skin Whitening Cosmetics Using ICP-AES, Int. J. Environ. Res. Public Health, 10, 361-374;

- AlsaffarN. Mohammed, jabber Huda H. , (2014) Determination of heavy metals in some cosmetics available in locally markets, J. of Environmental Science, Toxicology and Food Technology, 8 ( 8), 09-12

- Al-QutobM. AlatrashH. M and Abol-Ola Suhair, ( 2013) Determination of different heavy metals concentrations in cosmetics purchased from the Palestinian markets by ICP/MS, J. of the Bioflux Society, 5 (3),287-293.

- Agency for Toxic Substances and Disease Registry, (2012) Toxicological Profile for Cadmium, Centers for Disease Control and Prevention, Atlanta, Ga, USA, http://www.atsdr.cdc.gov/toxprofiles/.

- Amartey E.O., Asumadu-Sakyi A.B., Adjei C.A., Quashie F.K., Duodu G.O and Bentil N.O., (2011) Determination of heavy metals concentration in hair pomades on the Ghanaian market using atomic absorption spectrometry technique, Br. J.Pharmacol. Toxicol. 2(4), 192-198.

- BfR, BundesinstitutfürRisikobewertung. KosmetischeMittel,. BfRempfiehlt. SchwermetallgehalteüberReinheitsanforderungen der Ausgangsstoffezuregeln, StellungnahmeNr. 025/2006 des BfR 05. April (2006), Available at:http://www.bfr.bund.de/cm/343/kosmetische mittelbfrempfiehltschwermetallgehalte uber.pdf, 2006 (accessed 13.10.15).

- Bocca. B. Pino Anna, Alimonti Al. and Forte G.i, (2014) Toxic metals contained in cosmetics: A status report, J. Regulatory Toxicology and Pharmacology, 68, 447467.

- Chauhan A.S., Bhadauria R., Singh A.K., Lodhi S.S., Chaturvedi D.K.and Tomar V.S., (2010) Determination of lead and cadmium in cosmetic products, J. Chem. Pharm.Res. 2 92-97.

- Dghaim R., Al Khatib S., RasoolHusna, and Khan Munawwar Ali (2015) Determination of Heavy Metals Concentration in Traditional Herbs Commonly Consumed in the United Arab Emirates, J.of Environmental and Public Health , 1-6.

- Esemedafe U., Josephine; and Ogagaoghene. J. Akpoghelie, (2016) Assessment of $\mathrm{Hg}, \mathrm{Pb}, \mathrm{Cd}$, and As in Lip Gloss Samples purchase in an open market in Enugu State. Nigeria, J. of Scientific \&Engineering Research, 7 (12), 803-809. 
- Faruruwa Muhammad D., Bartholomew Stephen P., (2014) Study of heavy metals content in facial cosmetics obtained from open markets and superstores within Kaduna metropolis, Nigeria, American Journal of Chemistry and Application, 1 (2): 27-33.

- Health Canada-Santé Canada (HC-SC), (2012) Guidance on Heavy Metal Impurities in Cosmetics, Available at: http://www.hc-sc.gc.ca/cps-spc/pubs/industheavy metalsmetauxlourds/index-eng.php (accessed on 03.09.2014).

- Ibrahim S. Younes, Maguid R. A.and Al-Mazroua Maha Khaled, (2016) Evaluation of metals content among different cosmetic products in the Arabian market J. of Pharmacology and Toxicology, 4 (1), 53-58.

- Iwegbue C.M.A, Bassey F.I, Tesi G.O., Onyeloni, Sandy.O., Obi, G.and Martincigh, B.S., (2015) Safety evaluation of metal exposure from commonly used moisturizing and skin-lightening creams in Nigeria. Regul. Toxicol. Pharmacol. 71.484-490.

- Iwegbue C..M.A (2016a) Safety evaluation of metals in some brands of nail polish in Nigeria, Journal of Consumer Protection and Food Safety. 11 (3), 271-278 http://dx.doi.org/10.1007/s00003-016-1027-3.

- Iwegbue, C.M.A., Bassey, F.I., Obi, G., Tesi, G.O. and Martincigh, B.S. (2016c) Concentrations and exposure risks of some metals in facial cosmetics in Nigeria. Toxicol .Rep. 3, 464-472.

- Iwegbuea C. M.A., Emakunua O. S., Obib G., Godwin E. N.and Bice S. M. (2016b) Evaluation of exposure to metals from some commonly used hair care products in Nigeriahuman Toxicology Reports.3, 796-803.

- Iwegbue C. M.A. , Emakunu S. Omotekoro, Nwajei. Godwin E. Bassey Francisca I.and Martincigh Bice S., (2017) Evaluation of human exposure to metals from some commonly used bathing soaps and shower gels in Nigeria, Regulatory Toxicology and Pharmacology , 83, 38-45.

- KarimiG., Ziarati.P (2015) Heavy Metal Contamination of Popular Nail Polishes in Iran, J. of Toxicology, 9 (29). 1290-1295

- Liu Sa, Hammond S. Katharine, and Rojas-Cheatham Ann, (2013) Concentrations and Potential Health Risks of Metals in Lip Products, J. Environmental Health Perspectives, 121 (6), 705-710

- Nnorom I. C., Igwe J. C., OJI-Nnorom C. G., (2005) Trace metal contents of facial (make-up) cosmetics commonly used in Nigeria, African J. Biotech, 4, 1133-1138. 
- Nourmoradi H., Foroghi M., Farhadkhani M., and Dastjerdi M. Vahid, (2013) Assessment of Lead and Cadmium Levels in Frequently Used Cosmetic Products in Iran, J. of Environmental and Public Health, 1-5 .

- Nouioui Mohamed Anouar, Mahjoubi Salah, GhorbelAsma, YahiaMarouen Ben Haj, Amira Dorra, GhorbelHayet and HedhiliAbderrazek, (2016) Health Risk Assessment of Heavy Metals inTraditional Cosmetics Sold in Tunisian Local Markets International Scholarly $\quad$ Research $\quad$ Notices, $1-12$ http://dx.doi.org/10.1155/2016/6296458 .

- OrisakweO. and Otaraku Jonathan Oye, (2013) Metal Concentrations in Cosmetics Commonly Used in Nigeria, The ScientificWorld Journal, 1-7, http://dx.doi.org/10.1155/2013/959637.

- Salvador A., Pascual-Martı M.C, Arago'E, Chisvert A., March J.G., (2000) Determination of selenium, zinc and cadmium in antidandruff shampoos by atomic spectrometry after microwave assisted sample digestion. Talanta, 5(16), 1171-1177.

- Sanfilippo .A. MD, and English III C. Joseph., MD. (2006) an Overview of Medicated Shampoos Used in Dandruff Treatment, 31 (7), 396-400.

- Sukender K., Jaspreet S., Sneha D., Munish G., (2012) AAS estimation of heavy metals and trace elements in Indian herbal cosmetic preparations. Res. J. Chem. Sci, $2,46-51$.

- Ullah, H., Noreen, S., Fozia, Rehman, A., Waseem, A., Zubair, S., Adnan, M., Ahmad, I., (2013) Comparative study of heavy metals content in cosmetic products of different countries marketed in Khyber Pakhtunkhwa, Paskistan. Arab. J. Chem. 10, 10-18. http://dx.doi.org/10.1016/j.arabjc.2013.09.021.

- Umar M.A., Caleb H., (2013) Analysis of metals in some cosmetic products in FCTAbuja, Nigeria, Int. J. Cosmet. Sci. 3, 14-18.

- ZainyFaten M., (2015) Determination of Heavy Metals in 16 Bleaching Creams and 3 Mixtures of Bleaching Creams from Local Market of Jeddah, Egypt. J. Chem , 58 (3), 377- 386 . 